\title{
PENGALAMAN PADA PEGAWAI YANG MENGALAMI PEMOTONGAN GAJI DI
} MASA PANDEMI COVID-19

Oleh :

Michelle Elfreda Juangta,

Fakultas Psikologi, Universitas Surabaya

Email : s154220009@student.ubaya.ac.id

\section{Article Info}

Article History:

Received 13 Sept - 2021

Accepted 25 Sept - 2021

Available Online 25 Sept 2021

Keyword :

Eudaimonia Well-Being.

Pandemi, Covid-19,

Income.

\begin{abstract}
Concern for the quality of life is the center of attention in the current pandemic conditions. Environmental changes cause attention to be focused on the quality of life. The quality of life in question is in the concept of working during a pandemic and experiencing salary cuts. In this study, the researcher will use qualitative methods so that this event can be understood without any theoretical boundaries that separate the reader from the subject, but the reader can also feel, appreciate, and seem to be in the life of the subject. Through qualitative methods, data were collected by means of online interviews. The results of the event can be seen from the point of view of the author and the research subject. In this study, the research results were grouped into three main categories of responses as employees working during Covid-19. The first category is employees who have been dissatisfied with their situation since Covid-19, the second category is employees who are dissatisfied with their situation but are still trying to accept it since Covid-19, while the last category is the category of employees who are dissatisfied with their situation. kind and supportive. the course of company policies during the Covid-19 pandemic. This study has answered the research question that EWB is very important for working employees, because EWB affects work engagement and motivation. Decreased work motivation will affect the way employees work as well. Income is thought to be one of the factors that affect welfare because everything does require money. However, EWB can still be fulfilled during this Covid-19 pandemic despite a decrease in income.
\end{abstract}




\section{PENDAHULUAN}

Februari 2020 hingga 2021, badai krisis Covid-19 masih berjalan, namun kehidupan sosial dan ekonomi manusia sudah tidak bisa dibendung lagi. Sehingga setelah moment Idul Fitri 2020 pemerintah mulai memberlakukan New Normal bagi masyarakat sosial dan pelaku ekonomi dan industri. Kondisi pandemi ini mengakibatkan problematika ekonomi, diantaranya setiap organisasi atau perusahaan harus berusaha untuk survive. Hal ini mengakibatkan tuntutan atau demand perusahaan terhadap pegawai menjadi tinggi.

Sejumlah harapan diberikan kepada pegawai oleh organisasi atau perusahaan dalam rangka mempertahankan laju pergerakan bisnis perusahaan. Beberapa hal yang menjadi tuntutan antara lain : Organisasi harus lebih cepat tanggap untuk merespon tekanan eksternal untuk tetap menjalankan roda pertumbuhan organisasi. Covid19 membuat keadaan di semua organisasi kembali ke titik nol. Selain itu, organisasi diharapkan untuk selalu dapat mengantisipasi dan beradaptasi terhadap perubahan atau risiko yang mungkin terjadi. Selain itu dampak dari kebijakan dengan menjaga jarak atau social distancing, telah merubah pola perilaku dalam kehidupan sehari-hari. Bahkan cara kerja juga digantikan dengan metode daring atau virtual demi mencegah penyebaran pandemi Covid-19. Dengan demikian beberapa penyesuaian harus dilakukan menyesuaikan perubahan kebiasan kerja seperti mengadakan pelatihan secara daring, bekerja dari rumah hingga menyesuaikan kembali sistem penilaian kerja dan target dalam bekerja.

Tekanan organisasi dan sosial mengakibatkan gangguan pada kesejahteraan psikologis kepada orang-orang yang berusaha menyesuaikan setiap bentuk perubahan yang ada. Kesejahteraan psikologis mengacu pada pencapaian potensi seseorang. Adanya kesejahteraan psikologis pada individu memungkinkan individu tersebut untuk memiliki hubungan sosial yang mendukung, optimis, mencapai tujuan. Pada keadaan pandemi Covid-19 ini kesejahteraan psikologis mengalami gangguan, seperti yang ditunjukkan pada penelitian yang dilakukan oleh Tucson (2020) di Inggris dan Spanyol kepada 983 sukarelawan. Penelitian ini membagi prediktor kesejahteraan psikologis selama pandemi Covid-19 ini menjadi tiga bagian; kesehatan jasmani, kesehatan psikologis dan faktor sosial-ekonomi.

Jaminan kerja dan pendapatan, menjadi prediktor kesejahteraan psikologis selama pandemi Covid-19 karena selama pandemi, ada banyak individu yang kehilangan pekerjaan dan sumber pendapatan utama. Sumber daya pribadi ini berdampak pada kesejahteraan psikologis yang menurun akibat kekhawatiran akan kehilangan pekerjaan, tuntutan pekerjaan yang tinggi, stabilitas pekerjaan serta pendapatan yang menurun. Para peneliti menunjukkan bahwa kesejahteraan psikologis selama pandemi Covid-19 lebih rendah dibandingkan dengan kesejahteraan psikologis sebelum pandemi Covid-19.

Selama tiga bulan semenjak diumumkan kasus pertama Covid-19 pada bulan Maret 2020 oleh presiden Joko Widodo, pemerintah terus berupaya melakukan langkah-langkah mitigatif dan penanganan seoptimal mungkin agar virus ini tidak semakin menyebar dan membawa korban jiwa. Beragam pilihan kebijakan ditempuh untuk menghadang laju penyebaran, mulai dari penerapan physical distancing, hingga Pembatasan Sosial Berskala Besar (PSBB) di berbagai daerah yang terpetakan sebagai episentrum penyebaran. Pemerintah juga memberlakukan larangan mudik menjelang hari raya Idul Fitri.

Terlepas dari berbagai opsi kebijakan yang ditempuh, pemerintah Indonesia, seperti halnya pemerintah di negara lain, belum bisa memprediksi secara akurat kapan pandemi ini akan segera berakhir. Salah satu harapan terbesar agar pandemi ini bisa segera ditanggulangi adalah penemuan vaksin yang sedang diupayakan oleh berbagai ilmuwan di dunia. Namun demikian, seperti yang disampaikan oleh World Health Organization (WHO), temuan vaksin diperkirakan paling cepat dapat terlaksana pada 2021. Hal ini berarti, setidaknya sampai akhir tahun ini, seluruh masyarakat di dunia, tidak terkecuali Indonesia, harus membiasakan diri untuk hidup berdampingan dan berdamai dengan COVID-19. Selama vaksin belum ditemukan, masyarakat dihimbau untuk patuh menaati dan menjalankan protokol kesehatan yang telah ditetapkan oleh pemerintah.

Pandemi COVID-19 yang menghantam Indonesia selama tiga bulan terakhir tidak dipungkiri membawa pengaruh yang signifikan terhadap sektor perekonomian. Pemberlakuan PSBB secara langsung ataupun tidak, telah berdampak pada sektor industri yang harus mengurangi biaya produksi dengan menutup pabrik, merumahkan karyawan, hingga melakukan PHK, sebagai upaya rasional dalam merespons penurunan jumlah permintaan dan pendapatan. (Dinkes Bali, Agustus 2020). Perjalanan dan pengalaman dari pegawai yang masih bekerja namun mengalami pemotongan gaji inilah yang hendak peneliti coba kaji dalam penelitian ini. 
Pengalaman hidup individu berbeda satu dengan yang lainnya. Pengalaman yang menghasilkan kesejahteraan dalam hidupnya juga berbeda satu dengan yang lain. Cara pandang dan persepsi seseorang terhadap pengalaman hidupnya, terdiri dari evaluasi kognitif dan afeksi terhadap hidup yang dijalaninya dan merepresentasikan kesejahteraan.

Kesejahteraan atau Well-Being menurut Negovan (2010) merupakan konsep multikonstruk dan dapat dikelompokkan menjadi tiga level; yaitu Subjective Well-Being atau dapat disebut dengan Hedonia Well-Being. Psychological Well-Being atau dapat disebut dengan Eudimonia Well-Being, serta Social WellBeing atau dapat disebut Quality of Life.

Ada dua pendekatan teori yang digunakan dalam Subjective Well-Being atau kesejahteraan subjektif yaitu :

\section{Bottom up theories}

Teori memandang bahwa kebahagiaan dan kepuasan hidup yang dirasakan dan dialami seseorang tergantung dari banyaknya kebahagiaan kecil serta kumpulan peristiwaperistiwa bahagia. Secara khusus, kesejahteraan subjektif merupakan penjumlahan dari pengalaman-pengalaman positif yang terjadi dalam kehidupan seseorang. Semakin banyaknya peristiwa menyenangkan yang terjadi, maka semakin bahagia dan puas individu tersebut. Untuk meningkatkan kesejahteraan subjektif, teori ini beranggapan perlunya mengubah lingkungan dan situasi yang akan mempengaruhi pengalaman individu, misalnya: pekerjaan yang memadai, lingkungan rumah yang aman, pendapatan/gaji yang layak.

\section{Top-down theories}

Kesejahteraan subjektif yang dialami seseorang tergantung pada cara individu itu mengevaluasi dan menafsirkan suatu peristiwa-peristiwa dalam sudut pandang yang positif. Perspektif teoretis ini mempertimbangkan bahwa, individu lah yang menentukan atau memegang peranan apakah peristiwa yang yang dialaminya akan menciptakan kesejahteraan psikologis bagi dirinya. Pendekatan ini mempertimbangkan jenis kepribadian, sikap, dan cara-cara yang digunakan untuk menginterpretasi suatu peristiwa. Sehingga untuk meningkatkan kesejahteraan kebutuhan yang diperlukan berfokus pada mengubah persepsi, keyakinan dan sifat kepribadian seseorang.

Dalam perspektif bottom-up, kebahagiaan adalah akumulasi dari pengalaman bahagia dan hasil dari pemenuhan kebutuhan dasar. Dalam perspektif bottom-up, peristiwa menyenangkan sehari-hari dikaitkan dengan peningkatan pengaruh positif, dan peristiwa tidak menyenangkan sehari-hari dikaitkan dengan peningkatan pengaruh negatif. Dalam perspektif top-down berpendapat bahwa individulah yang menentukan dan memegang pernaan penting dalam menciptakan kesejahteraan psikologis bagi dirinya sendiri (Diener, 1984). Dengan kata lain, kesejahteraan individu mengakibatkan ia melihat dan bertindak dengan cara tertentu.

Sementara itu Psychological well-being adalah konsep yang berfokus pada pemaknaan dan realisasi diri dan mendefinisikan well-being sebagai "degree to which a person is fully functioning” (Ryan \& Deci, 2005). Ryff dengan mengutip pandangan Aristoteles, (dalam Ryan \& Deci, 2005) mendefinisikan well-being sebagai "the striving for perfection that represents the realization of one's true potential." Selain itu psychological well-being sendiri merupakan konsep yang memandang bahwa kebahagiaan tidak hanya sekadar tidak memiliki penyakit psikologis namun suatu kondisi positif yang membuat seseorang mampu memberdayakan potensi-potensi yang dimilikinya (Ryff dalam Ryan \& Deci, 2001).

\section{Penelitian Terdahulu Mengenai Eudaimonia Well-Being}

Dalam penelitian mengenai Eudaimonia WellBeing, terdapat beberapa penelitian terdahulu yang kemudian dijadikan sumber dalam penulisan ini. Penelitian mengenai Eudaimonia Well Being dilakukan pada tahun 2012 kepada maasyarakat di New Zealand mengenai seberapa penting penghasilan mempengaruhi kesejahteraan psikologis. Penelitian tersebut dilakukan menggunakan metode wawancara menggunakan media telepon. Hasilnya menunjukkan bahwa penghasilan berpengaruh kepada kepuasan hidup, dibandingkan dengan kesejahteraan psikologis, karena dianggap mampu memenuhi kebutuhan sehari-hari serta mampu menaikkan status social. Agnieszka B. dan Anna M. (2015) melakukan penelitian mengenai kaitan antara penghasilan dengan kesejahteraan psikologis dilakukan oleh). Penelitian ini dilakukan dengan metode interview dan observasi. Hasil menunjukkan bahwa penghasilan tidak berpengaruh secara signifikan kepada kesejahteraan psikologis.

\section{METODE PENELITIAN}

Pada penelitian ini, peneliti akan menggunakan metode kualitatif. Ciri khas penelitian yang menggunakan metode kualitatif menurut Semiawan (2014) adalah, mencari pengertian yang 
mendalam tentang suatu gejala, dan fakta atau realita, selain itu fakta, realita, masalah, gejala, serta peristiwa tidak dapat hanya dipahami bila peneliti tidak mendalaminya dan tidak hanya terbatas saja pada pandangan di permukaan saja.

Melalui metode kualitatif, peristiwa ini dapat dipahami tanpa ada batasan teori yang memisahkan pembaca dengan subjek, namun pembaca juga dapat merasakan, menghayati, dan seolah-olah berada dalam kehidupan subjek. Melalui metode kualitatif, suatu peristiwa dapat dilihat melalui perspektif penulis maupun subjek penelitian. Peneliti memilih metode penelitian kualitatif ini dikarenakan uraian penelitian sudah banyak melalui kuantitatif, dan peneliti ingin mendalami Eudaimonia Well-Being ketika dikaitkan dengan penghasilan.

Pada penelitian ini, paradigma didasarkan pada proses induktif, dimana konsep khusus yang menjadi konsep umum, konseptualisasi, kategorisasi, dan deskripsi dikembangkan berdasarkan masalah yang terjadi di lokasi penelitian. Penelitian ini memakai paradigma fenomologi. Fenomologi diartikan oleh Hebel (dalam Semiawan, 2014) sebagai apa yang dipersepsikan, dirasakan, dan diketahui oleh seseorang melalui peristiwa yang dialaminya secara sadar. Jadi kesadaran seseorang akan suatu pengalaman hidupnya menjadi kunci utama dalam paradigma fenomenologi. Pengalaman yang dirasakan oleh subjek adalah salah satu pengalaman yang menurutnya berharga, sebagai contoh pengalaman bekerja di masa pandemic Covid-19 dari awal bekerja, mengalami hal-hal menyenangkan di pekerjaan hingga mengalami hal kurang menyenangkan semasa bekerja dikarenakan adanya kontribusi.

Metode pengumpulan data dalam penelitian ini menggunakan metode wawancara dan observasi. Tujuan peneliti menggunakan metode ini adalah untuk mendapatkan informasi mengenai subjek secara mendalam, sehingga untuk mengetahui pengalaman well-being dalam pekerjaan dapat tergali dengan dalam. Tidak hanya melalui wawancara saja untuk mendapatkan data, namun melalui observasi juga.

Dimulai dengan meminta ijin untuk melakukan wawancara dan observasi, yaitu mengamati subjek penelitian beserta lingkungannya serta dilakukan dokumentasi berupa merekam audio atau bukti tertulis selama proses terjadi. Peneliti berada di keseharian subjek, dikarenakan subjek merupakan teman satu kantor dalam departemen yang sama. Peneliti juga melakukan pencatatan-pencatatan kecil terhadap subjek terkait dengan jam datang, jam pulang serta keluhan-keluhan yang dipaparkan.
Dalam penelitian ini, peran penting peneliti agar dapat memberikan subjek pernyataan persetujuan (informed content). Kegunaan informed content itu sendiri sebagai kontrak yang telah disetujui dari kedua belah pihak, baik dari pihak peneliti dan pihak subjek, sehingga peniliti mampu menjelaskan kode etik dari penelitian yang akan dipakai. Tidak hanya dari peneliti saja, namun subjek juga diharapkan mampu untuk memberikan data secara jelas dan benar selama tidak mengganggu privasi. (Shaughnessy, Zechmeister, Zechmesiter (2007, dalam Herdiansyah, 2015),

\section{HASIL DAN PEMBAHASAN}

Dalam penelitian yang dilakukan melalui metodologi observasi dan interview ini, dibagi menjadi tiga kategori utama respons sebagai pegawai yang bekerja selama Covid-19. Kategori pertama, adalah pegawai yang merasa tidak puas dengan keadaannya semenjak Covid-19, kategori kedua adalah pegawai yang merasa tidak puas dengan keadaannya namun masih berusaha untuk menerima semenjak Covid-19, sementara kategori terakhir adalah kategori pegawai yang merasa baik-baik saja dan mendukung jalannya kebijakan perusahaan selama pandemi Covid- 19.

Ketiga kategori tersebut dikelompokkan dilihat dari hasil observasi dan interview yang dilakukan kepada 3 subjek selama ini. Kategori pertama, dengan respon tidak puas, menghasilkan kinerja yang kurang baik di tempat bekerja. Pegawai yang merasa kurang puas dengan pekerjaannya, cenderung tidak engage dengan apa yang dia lakukan. Kategori kedua, dengan respon tidak puas dengan perusahaan, namun menyadari bahwan dirinya memikul tanggung jawab dalam pekerjaan, dan menjadikan keadaan tidak enak sebagai proses pengembangan diri. Kategori ketiga, dengan respon puas dengan perusahaan serta mendukung setiap usaha yang dilakukan oleh perusahaan untuk mempertahankan bisnisnya.

Pada ketiga subjek, semuanya mewakili masingmasing satu kategori dari pengelompokkan yang telah dibuat. Subjek pertama adalah subjek yang brada pada kategori pertama, yaitu merasa tidak puas dengan kebijakan perusahaan, dan menghasilkan demotivasi pada dirinya. Contoh paling mudah, adalah datang cenderung terlambat, tidak kunjung bekerja ketika sampai di kantor, serta jam istirahat cenderung tidak tepat waktu. Selain itu, perilaku yang terus menerus mengeluh serta mengajak rekan-rekan lain untuk sama-sama mengeluhkan kebijakan. Keluhan terkait target kerja diberikan oleh ketiga subjek selama proses wawancara karena Pandemi Covid-19 ini mengurangi keleluasaan setiap pegawai dalam menjalankan tugas pada pekerjaannya. 
Subjek pada kategori pertama juga tidak memiliki keinginan untuk mencari solusi dalam mencapai target kerja secara maksimal. Menurutnya, kejadian yang tidak dapat diusahakan akan selamanya tidak dapat diusahakan. Sementara subjek dalam kelompok kedua dan ketiga, masih mengusahakan target pekerjaan tercapai. Menurut subjek kelompok kedua, sangat penting baginya menyelesaikan tanggung jawab yang diembang oleh pegawai. Sementara subjek dalam kelompok ketiga sangat mendukung tindakan yang dilakukan perusahaan dalam usaha mempertahankan bisnis.

Pendapatan yang lebih tinggi dikaitkan dengan kesejahteraan yang lebih besar. Kehilangan jumlah pendapatan secara konsisten dapat mengurangi kesejahteraan secara perlahan, sebaliknya apabila pendapatan memang rendah, dan kemudian diberikan kenaikan secara bertahap, maka akan meningkatkan kesejahteraan secara perlahan (Boyce, et al., 2013). Kebijakan perihal pendapatan yang menurun, menyebabkan terjadinya menurunnya kesejahteraan secara perlahan.

Namun hal ini tidak nampak pada subjek kategori kelompok ketiga. Adanya Pandemi dan penurunan penghasilan tidak mempengaruhi minat dalam bekerja. Penurunan pendapatan dan pemotongan gaji bukanlah hal yang menjadi alasan utama pemilik usaha dan pegawai untuk tidak bersyukur. Namun berbeda dengan kedua subjek di kelompok kategori pertama dan kedua. Pemotongan gaji mempengaruhi minat dalam bekerja. Pemotongan gaji tidak sepadan, merambat kepada bonus akhir tahun yang didapatkan melalui pemenuhan KPI atau target tahunan untuk performance management dan sampai kepada kekecewaan akan kenaikan gaji di tahun 2021.

Sekalipun keduanya sama-sama mengalami kekecewaan dan penurunan minat dalam bekerja, namun subjek dalam kategori kelompok kedua memahami keadaan perusahaan, dan meyakini bahwa hal tersebut adalah hal terbaik yang dapat dilakukan pegawai untuk saat ini, bahkan Subjek tersebut pernah mempertanyakan pada dirinya sendiri, sebenarnya apa yang menjadi motivasinya dalam bekerja. Subjek dalam kategori kedua ini mengalami kekecewaan ketika mendapat potongan gaji. Namun Subjek masih mengusahakan untuk menjalankan apa yang menjadi kewajibannya terhadap pekerjaan, kecuali terkait jam datang yang menjadi mepet jam masuk (tidak terlambat) dan jam pulang yang tepat waktu (tidak bersedia lembur).

Dari hasil wawancara kepada tiga subjek tersebut, melalui metode interview ini telah menjawab pertanyaan penelitian bahwa Eudaimonia WellBeing diperlukan untuk pegawai karena berpengaruh terhadap motivasi kerja pegawai.

Ketika seorang yang memiliki Eudaimonia WellBeing yang tinggi, maka dia akan mampu tetap menjalankan kesehariannya dalam bekerja, tanpa mengurangi motivasi dan menurunkan performa dalam bekerja.

Kesejahteraan psikologis merupakan hal yang menjadi pusat perhatian pada keadaan pandemi saat ini. Dalam perkembangan sekarang, perubahan dalam lingkungan mengakibatkan orang-orang lebih memperhatikan aspek kesejahteraan psikologis. Tingkat kesejahteraan psikologis seseorang berkaitan dengan kemampuan berlaku positif yang terjadi dalam diri orang tersebut (Ryff, 1989). Dengan kata lain, kesejahteraan psikologis seseorang akan berkaitan dengan kemampuannya berfungsi secara psikologis dalam menjalani hidupnya. Dengan demikian, individu tersebut akan optimal dalam mengerjakan segala tugas dan tanggung jawabnya sebagai individu. Ia mampu menjalin hubungan yang baik dengan orang-orang di sekitarnya, ia juga akan mampu menyelesaikan tugas dan tanggung jawabnya. Spesifiknya, dalam dunia pekerjaan, maka tingkat kesejahteraan psikologis akan berguna dalam komitmennya terhadap pekerjaan, produktivitas individu, pencapaian target pekerjaan, hubungan dengan rekan kerja, serta penguasaan lingkungan kerja (Horn, 2004).

\section{KESIMPULAN}

Keadaan Pandemi Covid-19 mengakibatkan perusahaan terpaksa memberlakukan potongan gaji atau biasa disebut kontribusi untuk skala upah tertentu, yakni 5\% untuk gaji dibawah Rp $5.000 .000,-$. Potongan $10 \%$ untuk gaji Rp 5.000.000,- sampai Rp 10.000.000,-, serta potongan $17 \%$ untuk gaji di atas Rp $10.000 .000,-$. dan juga memberlakukan penghematan makan, penghematan listrik dan air, tidak membagikan seragam gratis di tahun ini (sebanyak dua pasang) dan juga penghilangan bonus tahunan yang biasanya skala pencapaiannya bisa satu sampai dengan delapan kali gaji bulanan.

Bagi sebagian pegawai, terkena kontribusi dan juga tidak mendapatkan bonus dan tunjangan tahunan ternyata bukanlah masalah bagi seluruh pegawai. Sebagian pegawai merasa tidak apa-apa bertahan dalam keadaan tersebut asalkan masih mendapatkan gaji tetap dan juga tidak terkena efisiensi atau PHK. Bagi sebagian dari mereka, hal ini adalah cara yang dapat dilakukan oleh perusahaan untuk menjaga agar perusahaan tetap bertahan dan tidak lapse. Dana yang dipotong dari gaji pegawai merupakan tunjangan tambahan untuk kesehatan para pegawai sendiri. Tindakan 
perusahaan dalam hal pemotongan gaji karyawannya memiliki tujuan yang jelas yaitu dikelola kembali, menjadi sumbangan alat kesehatan untuk menjaga keamanan dan kesehatan para pegawainya.

Peneliti menyadari bahwa salah satu aspek Eudaimonia Well-Being adalah Self-discovery, dimana menurut Norton (1976) Self-discovery adalah keadaan dimana seorang individu mampu untuk mengenal dirinya sendiri. Sehingga dalam penerapannya mencapai Eudaimonia Well-Being, seseorang sudah mampu mengenali dan hidup sesuai dengan daimon yaitu berjuang melalui realisasi diri. Dalam hal ini Subjek L (dalam kategori kelompok 1) dinilai belum mengenal dirinya lebih lanjut, apa yang dia inginkan dan harapkan terhadap pekerjaannya di perusahaan ini, sehingga hal tersebut dapat menjadi salah satu faktor Subjek L tidak menumbuhkan Eudaimonia Well-Being dalam kesehariannya bekerja. Subjek L tidak cukup melalui proses pengenalan dirinya, sehingga dalam bekerja ditambah dengan pemotongan gaji di masa pandemi ini memperkuat rasa tidak engagenya sehingga tidak memunculkan Eudaimonia Well-Being.

Hal ini sejalan dengan temuan dari D'Ambrosio, et al., (2020) bahwa pendapatan yang tidak berubah adalah salah satu prediktor kepuasan hidup. Hal lain yang membuat peneliti dan salah beberapa tim kerja di kantor merasa bahwa Subjek L melebihlebihkan perihal rasa kecewanya terhadap perusahan, adalah karena Subjek L pekerjaannya memang benar-benar ringan di waktu pandemi ini. Subjek L sendiri menyatakan dalam kutipan wawancaranya, bahwa semua pekerjaannya berhenti dan tidak ada hal lain yang dapat dia kerjakan karena kebijakan perusahaan. Sementara penulis dan beberapa anggota tim, tetap menjalankan kegiatan seperti biasa; yaitu keluar kota untuk kunjungan pabrik di Kota Gresik, Pasuruan dan Nganjuk namun dengan keadaan yang sama dengan Subjek L, yaitu pemotongan gaji $10 \%$, serta KPI tetap berusaha kami penuhi entah dengan tetap berkunjung ke pabrik dengan menggunakan protokol kesehatan seperti face shield atau juga melakukan pertemuan online menggunakan platform online meeting.

Sementara itu Subjek T (subjek dalam kategori kelompok 2) sekalipun mengeluh dan merasa demotivasi dalam bekerja, namun Subjek T masih terus melanjutkan bekerja, dan menyelesaikan pekerjaannya dengan baik sekalipun dibarengi dengan datang dekat dengan jam masuk kantor (tidak terlambat) dan pulang tepat waktu. Subjek T sendiri memiliki latar belakang bekerja selama kurang lebih 2 tahun, dan posisi saat ini sedang merencanakan pernikahan sehingga menurut
Subjek $\mathrm{T}$ ada banyak kebutuhan dana yang sebenarnya bisa dikumpulkan saat ini, namun jadi terhambat oleh pendapatan yang berkurang. Subjek $\mathrm{T}$ sebenarnya menunjukkan bahwa pegawai yang memiliki Eudaimonia Well-Being yang tinggi, akan menghasilkan rasa engage kepada tempatnya bekerja. Subjek $\mathrm{T}$ juga menjelaskan bahwa ketika dirinya mulai tidak termotivasi bekerja dan merasa curiga dengan perusahaan yang dirasa memotong gaji yang seharusnya tidak dipotong karena keadaan perusahaan sudah membaik, Subjek $T$ mengembalikan pandangannya akan pekerjaannya kepada dirinya sendiri. Subjek T berusaha untuk mempertanyakan dirinya, sebenarnya apa yang menjadi alasan dan motivasinya dalam bekerja di perusahaan ini. Ketika Subjek $\mathrm{T}$ mampu menjawab, bahwa sebenarnya apa yang menjadi motivasinya bekerja adalah dirinya sendiri diikuti dengan keinginan untuk berkembang, maka Subjek $\mathrm{T}$ mulai menyadari bahwa sebenarnya faktor pendapatan, bukanlah hal yang terutama dibandingkan dengan kesejahteraan dirinya sendiri.

Hal ini sejalan dengan salah satu aspek dari Eudaimonia Well-Being dilihat dari hasil wawancara yang dilakukan terhadap Subjek T, ia mampu memunculkan keinginan untuk bekerja demi kebaikan diri sendiri dan pengembangan dirinya. Subjek T mampu mengelola kekecewaan yang dimiliki, menunjukkan ia mampu menemukan sense of purpose and meaning in life dalam pengertian lingkungan kerja dan pekerjaannya. Subjek $\mathrm{T}$ mampu memunculkan rasa engage dan memunculkan Eudaimonia WellBeing dalam kesehariannya bekerja, karena Subjek $\mathrm{T}$ sudah mampu mengenal kemampuan dirinya, apa yang dia inginkan dan memunculkan keinginan untuk bekerja di perusahaan adalah keinginannya untuk berkembang.

Hal ini sejalan dengan apa yang pernah diungkapkan oleh Diener dan Oishi kepada sepuluh ribu responden yang berasal dari 48 negara. Dalam penelitian yang dilakukan, ditemukan peringkat rata-rata kebahagiaan merupakan peringkat tertinggi dibandingkan 12 atribut lainnya, termasuk di atas "kesuksesan", "pengetahuan" dan "kesejahteraan material" (Diener, 2009). Hal ini dapat disimpulkan bahwa orang rela mengorbankan uang (yang sebelumnya dianggap sebagai materi terpenting) untuk mencapai kebahagiaan. Penulis sendiri mengenal dengan baik Subjek T, dimana sebenarnya Subjek $\mathrm{T}$ merupakan pegawai yang berpotensi untuk promosi jabatan, dan memiliki keahlian di atas rata-rata. Namun ternyata Subjek T tidak 'menilai' dirinya secara berlebihan, dan masih mau 
memahami keadaan perusahaan saat ini. Dengan tidak melabel nilai dirinya lebih tinggi dibandingkan pendapatan yang dia terima, membuat Subjek T mampu memaknai tujuan dia bekerja di perusahaan ini. Hal ini menimbulkan Eudaimonia Well-Being dalam dirinya yang meningkatkan engagement pada perusahaan. Mengutamakan kesejahteraan dibandingkan dengan pendapatan juga merupakan hal yang tampak dengan sangat jelas pada Subjek J (subjek pada kelompok kategori ketiga).

Saat ini posisi Subjek J tinggal sendiri di Pulau Bali, jauh dari keluarga dan sudah bekerja selama 6 tahun di Bali. Keadaan saat ini Subjek J belum menikah sehingga memiliki posisi yang kurang lebih keadaannya setara dengan Subjek $\mathrm{T}$ yang sedang merencanakan pernikahan, dan Subjek L yang sudah menikah namun suami juga berpenghasilan, belum memiliki anak dan tinggal dengan kedua belah pihak orang tua.

Pekerjaan Subjek J sebagai salah satu Area Manager Coffee Shop di Bali merupakan posisi yang sebenarnya mendapatkan potongan gaji atau pengurangan pendapatan yang cukup besar dibandingkan Subjek $\mathrm{T}$ dan Subjek $\mathrm{L}$ yang posisinya sebagai staff di perusahaan manufaktur. Selain potongan gaji yang lebih besar, Subjek J dengan posisi manager juga memiliki tanggung jawab yang lebih besar dibandingkan Subjek T dan Subjek L. Namun hal yang istimewa dan membedakan Subjek $\mathbf{J}$ dengan kedua subjek lainnya, adalah keinginannya untuk dapat berkarya dengan baik dan bernilai bagi perusahaan, bahkan mengajukan diri untuk bekerja lebih dan mengurangi pendapatan demi kebutuhan operasional.

Subjek J memiliki Continuance Comitment dalam Komitmen Organisasi, dikarenakan apa yang dilakukan oleh Subjek J menunjukkan keinginan untuk tetap berada di organisasi dalam waktu yang panjang, karena merasa sudah menuangkan energi dan merasa engage dengan organisasi baik secara mental dan emosional. Hal ini juga nampak dari rutinitas yang dilakukan Subjek $\mathbf{J}$ sehari-hari dimana posisi tinggalnya ada di Denpasar, sementara lokasi store ada di Denpasar dan Jimbaran yang memakan waktu untuk menuju ke sana hampir setiap hari. Selain itu keseharian Subjek J juga diceritakan sebagai individu yang dengan sukarela melakukan kegiatan keseharian yang bukan merupakan bagiannya, namun bersedia dikerjakan tanpa instruksi. Oleh karena itu, tidak heran Subjek J mampu 'memaksakan' dirinya dan tim untuk senantiasa mencari jalan keluar dari setiap permasalahan yang ada.

Sebuah tindakan yang muncul dari dirinya sendiri menunjukkan upaya luas biasa dalam mengejak keunggulan. Sunjek J juga mampu engage dan mencapai keadaan Eudaimonia ketika dia berhasil menginvestasikan dan mengusahakan upaya di tempatnya terlibat, hal ini berkaitan dengan salah satu aspek dari Eudaimonia Well-Being yaitu Investment of Significant effort in pursuit of excellence. Subjek J mampu menjalankan kesehariannya walau dianggap tidak enak dan tidak menyenangkan oleh orang lain, namun Subjek J mampu bekerja dengan baik bahkan memberikan porsi lebih.

Penelitian mengenai Eudaimonia Well-Being di tempat bekerja pada masa pandemi melalui metode interview ini menyimpulkan bahwa Eudaimonia Well-Being sangat penting untuk pegawai yang bekerja, dikarenakan Eudaimonia Well-Being berpengaruh terhadap motivasi bekerja. Motivasi bekerja yang menurun akan memengaruhi cara bekerja pegawai juga. Salah satu factor yang menentukan motivasi bekerja adalah uang atau penghasilan. Penghasilan diduga dapat menjadi salah satu factor yang mempengaruhi kesejahteraan dikarenakan segalanya memang membutuhkan uang. Namun Eudaimonia WellBeing tetap dapat terpenuhi pada masa pandemi Covid-19 ini sekalipun terdapat penurunan penghasilan. Perspektif ini menempatkan dua orang subjek yang tetap fokus pada makna dalam hidup dan realisasi diri, dalam pekerjaannya dan sejauh mana seseorang sepenuhnya mengintegrasikan kesejahteraan ini ke dalam hidupnya. Sementara seorang subjek menunjukkan perspektif hedonis, dimana individu menekankan dan mengasumsikan bahwa kesejahteraannya tergantung kepada pencapaian dan penghasilannya dalam pekerjaan

\section{REFERENSI}

(2013). OECD Guidelines on Measuring Subjective Well-being. In OECD Guidelines on Measuring Subjective Wellbeing. https://doi.org/10.1787/9789264191655en

AL, A. (2017). Analisis Indeks Kebahagiaan di Indonesia. Universitas Tanjungpura, 1-14.

Areepattamannil, S., \& Hashim, J. (2017). The questionnaire for Eudaimonic well-being (QEWB): Psychometric properties in a non-western adolescent sample. Personality and Individual Differences, 117(October 2017), 236-241. https://doi.org/10.1016/j.paid.2017.06.018

Avey, J. B., Reichard, R. J., Luthans, F., \& Mhatre, K. H. (2011). Meta-analysis of the impact of positive psychological capital on employee attitudes, behaviors, and 
performance. Human Resource Development Quarterly, 22(2), 127-152. https://doi.org/10.1002/hrdq.20070

Bartels, A. L., Peterson, S. J., \& Reina, C. S. (2019). Understanding well-being at work: Development and validation of the eudaimonic workplace well-being scale. PLoS ONE, 14(4), 1-21. https://doi.org/10.1371/journal.pone.0215 957

Bryce, A. (2018). Finding meaning through work: eudaimonic well-being and job type in the US and UK. Sheffield Economic Research Papers, 2018004, 39.

Chan, K. M., Gould, R. K., \& Pascual, U. (2018). Editorial overview: Relational values: what are they, and what's the fuss about? Current Opinion in Environmental Sustainability, $\quad 35, \quad$ A1-A7. https://doi.org/10.1016/j.cosust.2018.11.0 03

Czerw, A. (2019). Diagnosing Well-Being in Work Context - Eudemonic Well-Being in the Workplace Questionnaire. Current Psychology, 38(2), 331-346. https://doi.org/10.1007/s12144-017-96148

der Kinderen, S., \& Khapova, S. N. (2020). Positive Psychological Well-Being at Work: The Role of Eudaimonia. The Palgrave Handbook of Workplace WellBeing, 1-28. https://doi.org/10.1007/9783-030-02470-3_79-1

der Kinderen, S., Valk, A., Khapova, S. N., \& Tims, M. (2020). Facilitating eudaimonic well-being in mental health care organizations: The role of servant leadership and workplace civility climate. International Journal of Environmental Research and Public Health, 17(4). https://doi.org/10.3390/ijerph17041173

Eko, I., Ridwan, S. M., Arsepta, S., \& Sandra, K. (2020). Hubungan Antara Pendapatan Terhadap Kesejahteraan Subjektif Pada Anggota Tni Au Di Kota X. 13(2), 1-4.

Fisher, C. D. (2014). Conceptualizing and Measuring Wellbeing at Work. Wellbeing, July, $1-25$. https://doi.org/10.1002/9781118539415.w bwell018

Hanifah, N. F., \& Saifanah, S. N. (2020). Contribution of Learning Independence on the Achievement of Mathematical Learning Outcomes of Geometry Transformation Materials School Students. Journal Of Educational Experts (JEE),
$3(1)$, 31. https://doi.org/10.30740/jee.v3i1p31-38

Harding, T., Lopez, V., \& Klainin-Yobas, P. (2019). Predictors of Psychological WellBeing among Higher Education Students. Psychology, 10(04), 578-594. https://doi.org/10.4236/psych.2019.10403 7

Hefferon, K., \& Boniwell, I. (n.d.). Psychology. Horn, J.E.V., Taris, T.W., Schaufeli, W.B., \& Schreurs, P.J.G. (2004). The structure of occupational wellbeing: A study among dutch teachers. Journal of Occupational and Organizational Psychology, 77, 365375

Huta, V., \& Waterman, A. S. (2014). Eudaimonia and Its Distinction from Hedonia: Developing a Classification and Terminology for Understanding Conceptual and Operational Definitions. Journal of Happiness Studies, 15(6), 1425-1456. https://doi.org/10.1007/s10902-013-94850

Ibrahim, M. M. S., \& Amari, A. A. (2018). Influence of the Psychological Capital and Perceived Organizational Support on Subjective Career Success: The Mediating Role of Women's Career Adaptability in the Saudi Context. International Journal of Business and Management, 13(9), 189. https://doi.org/10.5539/ijbm.v13n9p189

Kaira, A. (2017). Decoding the Bland-Altman Plt: Basic Review. Journal of the Practice of Cardiovascular Sciences, 3(January), 36-38. https://doi.org/10.4103/jpcs.jpcs

Knippenberg, L., de Groot, W. T., van den Born, R. J., Knights, P., \& Muraca, B. (2018). Relational value, partnership, eudaimonia: a review. Current Opinion in Environmental Sustainability, 35, 39-45. https://doi.org/10.1016/j.cosust.2018.10.0 22

Lazar, V. A., \& Monson, W. G. (1965). ESTIMATION OF FECAL OUTPUT-XRay Spectrographic Determination of Chromic Oxide in Steer Feces. Journal of Agricultural and Food Chemistry, 13(2), 161-163. https://doi.org/10.1021/jf60138a019

Mohebi, S., Parham, M., Sharifirad, G., \& Gharlipour, Z. (2018). Social Support and Self - Care Behavior Study. 1-6. https://doi.org/10.4103/jehp.jehp

Needs, H., Principle, P., \& Well-being, S. (2009). Psychological Well-Psychological 
Well-Being Psychological Well-Being Ryff , 1989 Psychological Well Being.

Of, O. L. E., \& Of, E. (2012). T He R Ole of F Oresight in the. Reproduction, 3(2), 635641.

Ortner, C. N. M., Corno, D., Fung, T. Y., \& Rapinda, K. (2018). The roles of hedonic and eudaimonic motives in emotion regulation. Personality and Individual Differences, 120(June 2017), 209-212. https://doi.org/10.1016/j.paid.2017.09.006

Peiró, J. M., Kozusznik, M. W., \& Soriano, A. (2019). From happiness orientations to work performance: the mediating role of hedonic and eudaimonic experiences. International Journal of Environmental Research and Public Health, 16(24). https://doi.org/10.3390/ijerph16245002

Rothausen, T. J. (2013). Hedonic and Eudaimonic Enjoyment of Job and Fulfillment of Job Purpose.

Salavera, C., Usán, P., Teruel, P., \& Antoñanzas, J. L. (2020). Eudaimonic Well-being in adolescents: The role of trait emotional intelligence and personality. Sustainability (Switzerland), 12(7), 1-11. https://doi.org/10.3390/su12072742

Salman, A., Sellami, M., Al-Mohannadi, A. S., \& Chun, S. (2019). The associations between mental well-being and adherence to physical activity guidelines in patients with cardiovascular disease: Results from the scottish health survey. International Journal of Environmental Research and Public Health, 16(19), 1-13. https://doi.org/10.3390/ijerph16193596

Schutte, L., Wissing, M. P., \& Khumalo, I. P. (2013). Further validation of the questionnaire for eudaimonic well-being (QEWB). Psychology of Well-Being, 3(1). https://doi.org/10.1186/2211-1522-3-3

Serban-Oprescu, G. L., Dedu, S., \& SerbanOprescu, A. T. (2019). An integrative approach to assess subjective well-being. A case study on Romanian university students. Sustainability (Switzerland), 11(6). https://doi.org/10.3390/su11061639

Sharma, S., Conduit, J., \& Rao Hill, S. (2017). Hedonic and eudaimonic well-being outcomes from co-creation roles: a study of vulnerable customers. Journal of Services Marketing, 31(4-5), 397-411. https://doi.org/10.1108/JSM-06-20160236

Sheykhangafshe, F. B., \& Shabahang, R. (2020). The Role of Resilience and Mindfulness in Predicting the
Psychological Well-Being of Mothers of Children with Autism. March.

Su, L., Tang, B., \& Nawijn, J. (2020). Eudaimonic and hedonic well-being pattern changes: Intensity and activity. Annals of Tourism Research, 84(July). https://doi.org/10.1016/j.annals.2020.1030 08

Tomer, J. F. (2011). Enduring happiness: Integrating the hedonic and eudaimonic approaches. Journal of Socio-Economics, 40(5), 530-537. https://doi.org/10.1016/j.socec.2011.04.00 3

True, N., Absolutely, U., Mostly, U., Absolutely, T., Steger, M. F., Work, T., \& Inventory, M. (2011). The Work and Meaning Inventory. Work can mean a lot of different things to different people. The following items ask about how you see the role of work in your own life. Please honestly indicate how true each statement is for you and your work.

Tumanggor. (2017). PERBEDAAN ANTARA PENDEKATAN HEDONIS DAN EUDAIMONIS ATAS QUALITY OF LIFE : KAJIAN FILOSOFIS ( Prosiding Forum Ilmiah Psikologi Indonensia 23-27 Agustus 2016 Fak. Psikologi Universitas ... August 2016.

Turban, D. B., \& Yan, W. (2016). Relationship of eudaimonia and hedonia with work outcomes. Journal of Managerial Psychology, 31(6), 1006-1020. https://doi.org/10.1108/JMP-07-20150271

Turban, D. B., \& Yan, W. (2016). Relationship of eudaimonia and hedonia with work outcomes. Journal of Managerial Psychology, 31(6), 1006-1020. https://doi.org/10.1108/JMP-07-20150271

Turóczy, Z., \& Marian, L. (2012). Multiple Regression Analysis of Performance Indicators in the Ceramic Industry. Procedia Economics and Finance, 3(12), 509-514. https://doi.org/10.1016/s22125671(12)00188-8

Waterman, A. S., Schwartz, S. J., Zamboanga, B. L., Ravert, R. D., Williams, M. K., Bede Agocha, V., Kim, S. Y., \& Brent Donnellan, M. (2010). The questionnaire for eudaimonic well-being: Psychometric properties, demographic comparisons, and evidence of validity. Journal of Positive Psychology, 5(1), 41-61. 
https://doi.org/10.1080/174397609034352

08

York, C. (2017). A regression approach to testing genetic influence on communication behavior: Social media use as an example. Computers in Human Behavior, 73, 100-109. https://doi.org/10.1016/j.chb.2017.03.029

Yu, L. (2014). A study of english reading ability based on multiple linear regression analysis. Journal of Chemical and Pharmaceutical Research, 6(6), 18701877.

Zuo, S., Wang, S., Wang, F., \& Shi, X. (2017). The behavioural paths to Wellbeing: An exploratory study to distinguish between hedonic and eudaimonic Wellbeing from an activity perspective. Journal of Pacific Rim Psychology, 11, 1-13. https://doi.org/10.1017/prp.2017.1 
